\title{
Tragic and Heroic Moments in the Lives of Forced Migrants: Memories of Political Asylum-Seekers in Post-Apartheid South Africa
}

\author{
ERNEST A. PINETEH AND THECLA N. MULU
}

\begin{abstract}
This article examines the memories of a group of Cameroonian asylum-seekers in South Africa, analyzing personal accounts of memories of fear, suffering, and pain as well as resilience and heroism during their forced migration. The article argues that the legitimacy of applications for asylum often depends on accurate and consistent memories of specific life-threatening episodes at home and during migration. Drawing on theoretical conceptions such as construction of memory, autobiographical memory, and politics of storytelling, this article teases out how personal memories of asylum-seekers provide a discursive space to access and understand the asymmetries of seeking political asylum in post-apartheid South Africa.
\end{abstract}

\section{Résumé}

Cet article étudie les souvenirs d'un groupe de chercheurs d'asile d'origine camerounaise en Afrique du Sud. Il analyse leurs témoignages personnels de souvenirs associés à la peur, la souffrance et la douleur, ainsi que ceux de la persévérance et de l'héroïsme lors de leur migration forcée. L'article maintient que la légitimité des demandes d'asile dépend souvent des souvenirs précis et cohérents de situations spécifiques impliquant un danger de mort qu'ils ont subies dans leurs pays ainsi que lors de la migration. En faisant appel à des conceptions théoriques telles que la construction de la mémoire, la mémoire autobiographique, et la politique des récits narratifs, l'article fait ressortir la façon dont les souvenirs personnels des chercheurs d'asile produisent un espace discursif pour accéder et comprendre la dimension asymétrique inhérente à la recherche d'un asile politique en Afrique du Sud post-apartheid.

\section{Introduction}

I n the asylum application process, "the decisions [to grant political asylum] very often rest on a judgement whether or not the claimants and their story are credible." This entails "the ability to recall specific memories" in a narrative that is deemed consistent and coherent by the asylum determination officers. ${ }^{2}$ Although experiences of forced migrants are those of fear, pain, and suffering, which they would rather forget than remember, the inclusion of specific details of key moments in their lives is often construed as a marker of credibility. ${ }^{3}$ This approach to asylum narratives lends itself to "the question of the relationship between 'facts' and emplotment, truth and representation."4

In the case of South Africa, the legitimacy of claims for political asylum resides not only in the techniques of narrative construction but also in the recollection of life-threatening experiences at home and during the journey to exile.5 However, because of the inadequacy of resources to manage the increasing influx of asylum-seekers, and the prescripts of the South African immigration policies such as the infamous Aliens Control Amendment Act of 1995 or Refugees Act of 1998, the term illegal immigrants remains the dominant discourse and often is used as a pretext to reject applications of 
bona fide asylum-seekers. ${ }^{6}$ Certain immigration policies have been amended to respond to the changing characteristics of global human mobility, but stories of asylum-seekers from war-torn countries like the Democratic Republic of Congo (DRC) and Somalia are often privileged by the refugee determination officials because of South African media coverage of devastating wars in these countries.7 For Cameroonians, this process entails remembering moments of immeasurable suffering, fear, and pain, as well as feats of heroism in a country rated by South Africa as politically stable and therefore a non-refugee-producing country. ${ }^{8}$

To understand the subjectivity of Cameroonians' exilic experiences, we need to examine how these experiences are recalled and how Cameroonian asylum-seekers "build themselves into the world by creating meaning [and] by fashioning out of [traumatic images], a sense of what the world is all about."9 In this article, we discuss how Cameroonian applicants for asylum in South Africa construct memories of personal and collective experiences in a tragic sense and/or as a process of self-styling, to enhance the credibility and reliability of their applications. ${ }^{10}$ The article uses phraseology associated with conventional principles of tragedy, but in this case we use the term loosely as a prism through which to make meanings from Cameroonian memories of physical and psychological pain encountered during the process of forced migration.

This article argues that the re-storying of forced migrant experiences is primarily the remembering or forgetting of personal episodes of displacement, whereby the narrators represent themselves as victims at home and heroes during flight to exile. ${ }^{11}$ This process of memory work establishes a relationship between the context and individual meanings of the self in the diaspora and of intricacies of political asylum in the South African context. Here, the self can only be understood in relation to the Other, in this case the political or social context of the asylee. ${ }^{12}$ The article therefore attempts to connect the dots between personal memories and social realities, showing how Cameroonian memories "function to construct the social reality that constitutes the lived world of social actors." 13

\section{A Brief Conceptual Framework}

To understand how Cameroonian asylum claimants remember tragic and heroic experiences of displacement, this article uses conceptual lenses such as the process of memory work, autobiographical memory, and the politics of storytelling. For example, recalling exilic experiences is in fact a gradual process of memory work. ${ }^{14}$ It is a "journey into the memory and imagination that negotiates between old and new, past and present, self and other, safety and danger." 15 The urgency to engage in memory work is the result of a major rupture in the life of an individual that needs to be remembered or forgotten. ${ }^{16}$ When an experience is remembered, "it assumes the form of narrative of the past that charts the trajectory of how one's self came to be."17 Thus, memories of asylum-seekers are journeys into their past, which help us to make sense of their present social conditions in exile and predict their futures.

The meanings of our lives are often buried in our memories, and the transformation of memories into narrative gives us a sense of place and time. ${ }^{18}$ The "representation of past examples of participation in life events in a life story format, provides continuities of that participation across time and place." ${ }^{9}$ These memories "are practices of formation where systems of power are constructed, resisted, subverted and mediated in, and through linguistic agency." ${ }^{20}$ In this article, the memories of Cameroonian asylum-seekers "help to secure the identities that enable [them] to navigate, legitimate or resist the present order of things." 21 This means that they are able to use the process of remembering to define who they have been and who they would like to be in the future, and to find comfort during present struggles. ${ }^{22}$

The memories of Cameroonian asylum-seekers detailed here should be read as self-orderings of personal experiences. In recollecting experiences of displacement, narratives of asylum-seekers are indeed autobiographical memories of home, flight, and exile, which entail "an explicit 'memory' of an event [or events] that occurred in a specific place in one's personal past." 23 The concept of autobiographical memory is about making sense of personal experiences that are spatially and temporally based, and therefore "the function of human autobiographical memory is not to remember exact/ accurate memories of events," as these can be "subject to distortions as well as failure." 24 Although the determination of asylum leans towards accuracy, consistency, and credibility, Cameroonian asylum-seekers' memories are stories of displacement that are always constructed and reconstructed by individual narrators. ${ }^{25}$ Here, Cameroonian recollections of historical and socio-political events at home and in exile as well as the imaging of the self as a hero and a victim in these events articulate a "relationship between individual consciousness and the social world." 26

Since memory work and autobiographical memory are framed around the way individuals remember and retell episodes of their social experiences, this article has also drawn on the politics of storytelling as a conceptual frame. Human beings make meanings of their worlds through storytelling. ${ }^{27}$ The stories that human beings tell about their experiences involve "an ongoing struggle to negotiate, reconcile, balance or mediate ... antithetical potentialities of being." 28 This means human lives are storied lives, in that "telling the story of the life we have lived thoroughly and 
deeply shows us the powerful presence of archetypes, those common elements of being human that others, throughout time and across all cultures, have also experienced in their lives." ${ }^{29}$ Cameroonian asylum-seekers' memories are therefore stories that provide agency in the process of seeking asylum, a sense of selfhood, and a way for us to make sense of their social existence in a country like South Africa, fraught with anti-foreigner sentiments. ${ }^{30}$

\section{The Challenge of Obtaining Political Asylum in Post-Apartheid South Africa}

One of the many challenges the South African government faces is managing the increasing number of asylum-seekers and economic migrants entering the country. ${ }^{31}$ The government's inability to regulate the entry of displaced persons as well as to address critical social problems such as unemployment, poverty, and crime has resulted in powerful antiforeigner sentiments. These sentiments have been expressed in several gruesome attacks aimed at exorcising particularly African migrants from South Africa. ${ }^{32}$ Although the xenophobic attacks on Africans are criminalized, this prevalent culture is arguably "the struggle of the poor for citizenship [which] includes defining who is inside and who is outside." 33 For a perennially poor South African, the presence of Africans poses "an existential threat to South Africa's collective transformation and renaissance." 34 In this context, Africans are repeatedly represented as the demons, "the source of HIV/AIDS, the primary cause of crime, and a threat to South Africa jobs and cultural values." 35

Interestingly, the discourse of the "rainbow nation" and the celebration of the country's diversity seem to criminalize "blackness" while legitimizing the value of "whiteness" in South Africa. ${ }^{36}$ Moreover, media narratives referring to Africans "as masses flooding into South Africa illegally" 37 exacerbate the conditions of African migrants in South Africa. The article thus argues that "despite the transition from authoritarian rule to democracy, prejudice and violence continue to mark contemporary South Africa." 38 Therefore, to acquire political asylum in the new South Africa, applicants are expected to provide accounts that are acceptable by the institutions of the state. ${ }^{39}$ In the case of Cameroonians, "the institutional context" 40 plays a key role in influencing the way they narrate their experiences of forced displacement to the South African refugee determination officials.

\section{Methods of Data Collection}

The article attempts to make meanings from the memories of Cameroonians seeking political asylum in Johannesburg, South Africa. Their stories are seen as frames of legitimacy and illegitimacy, whereby the contents are used during the asylum determination process to include and exclude. ${ }^{41}$ The article draws on stories told by twenty Cameroonians who applied for asylum between 1996 and 2004. To select the participants, we contacted a specific group of Cameroonians who entered South Africa between 1996 and 2004 allegedly as political refugees ${ }^{42}$ and applied for asylum during this period. Only those who consented were interviewed. One of the researchers lived in the Johannesburg-based Cameroonian community for more than ten years and had access to the participants. As the researcher, his role was to mitigate bias in the interviews and to provide an unrestricted space for participants to speak freely about their experiences of displacement and seeking asylum.

At time of the research, the respondents resided in Berea, Braamfontein, Hillbrow, and Yeoville, intersections of the Johannesburg inner city. We focused on these areas because Africans living in these spaces "share ancestries, traditions and languages." 43 In addition, they tend to cluster in these spaces because they have been appropriated and reinvented as migrant ghettos. In terms of demographics, the participants comprised fourteen men and six women between the ages of twenty-five and fifty-five, predominantly students and professionals as well as formal and informal business owners. These demographics reflect the characteristics of the Cameroonian population in South Africa at the time of this research. 44

The data were collected by conversational individual interviews, focused on the political atmosphere in Cameroon, the process of fleeing the country, and participants' experiences as forced migrants seeking political asylum in South Africa. Each interview was preceded by an explanation of the purpose of the study, and all the interviewees signed consent forms granting the researchers permission to conduct and record the interviews, and guaranteed confidentiality. Participants are thus quoted as "participant" and a suffix number between 1 and 20 .

For data analysis, the researchers use a narrative study approach to unlock the way the participants remembered their lived experiences. This approach focuses on aspects of storytelling, the construction of memory, and autobiographical memory embedded in the stories and the implications for their asylum applications in post-apartheid South Africa. Finally, it concentrates on the linkages between Cameroonian memories and our understanding of Cameroonians' reconstructions of their political identities and life histories as embodiments of pain, suffering, and resilience, at home and in exile. ${ }^{45}$

\section{Memories of Tragic and Heroic Moments in the Lives of Cameroonian Asylees}

In South Africa, the refugee determination process relies on two pieces of evidence: the personal narratives of applicants and the refugee determination panel's knowledge of the 
country of origin. As stated above, decision to grant asylum is sometimes based on media images and narratives that classify particular countries as politically stable and therefore not refugee-producing countries. ${ }^{46}$ At the time of this research, many Cameroonian applications had been rejected on these grounds. By defining refugees narrowly as victims of politically unstable countries, the South African refugee determination officers were in direct contravention of the 1951 Geneva Convention, which defines asylum-seekers as "individuals in fear of being persecuted for reasons of race, religion, nationality, membership of a particular social group or political opinion." 47 This means that Cameroonian narratives had to be compelling enough to dispel these perceptions about Cameroon. The memories of the group of Cameroonians who entered South Africa as asylum-seekers between 1996 and 2004 were meant to counter the hegemonic discourse about Cameroon. ${ }^{48}$ One narrative strategy in their stories was the conflicting representation of episodes of resilience, heroism, and victimization in a series of seemingly tragic events. Here, narrators attempt to frame their accounts around tragic characteristics of suffering, fear, and pity, while plotting the narratives in three interrelated phases: the participants' lives in Cameroon, their experiences of flight, and their days in exile.

To endorse their experiences of forced migration, the participants represent themselves as the main protagonists in their own stories and as victims of tragic circumstances at home, during flight and in exile. For example, one participant commences his testimony by profiling himself as a charismatic and astute student leader at a university in Cameroon and his vision of transforming his university into a "world class" space for learning. For him, this vision pitted him against the university's top management and eventually against the country's ruling party. He also describes himself as a partisan supporter of the political ideologies of the main opposition political party in Cameroon-the Social Democratic Front. Choosing the path of student leadership in an undemocratic space like Cameroon means that resistance and conflict with university management are expected.

During the interview, he intelligently reconstructed a familiar story about student leadership in Cameroon into a deeply powerful and emotional testimony, portraying himself as a hero who contributed significantly to fostering student politics in higher education. For him, these moments in his life marked the beginning of an uncharacteristic political history, which eventually resulted in pain, suffering, and despair. 49 The participant's testimony begins organically with an elaborate and somewhat glamorous account of his political life:
Prior to my being elected the Student Union president, sometime in 1994, I have been actively involved in lots of issues that had clear-cut political implications in Cameroon. I had been actively involved in the Cameroon Anglophone Movement. I led the final struggle that led to the installation of the $\mathrm{GCE}$ Board 50 in Cameroon. I led that final demonstration. Everything that took place during that time was purely under my control. I did all the coordination from Yaounde to Buea to Bamenda; it was well known that I was behind everything. So at the point even before I came to the university, I was already noted for such activities, but because it wasn't really an issue at that time, it did not hamper my entry into the university. But having been admitted and subsequently elected as the Student Union president, due to my beliefs ... I had certain beliefs; I tried to transform the university through these beliefs and my political ideologies. After the Cameroon Anglophone Movement, I immediately subscribed to the political ideology of the Social Democratic Front as a student leader. The university did not like my leadership style and I fell out with the management. ${ }^{51}$

The most important aspect of this testimony is the way the participant shapes his story as that of a man imagining his political identity and destiny. In creating credibility, his testimony focuses on painful actions that elevate his status as political asylee. It represents the respondent as "the only man in action ... action that involves the ultimate risk and pushes him to his very limits." 52 In the South African asylum determination process, a story about student leadership without any turbulent political twist is not a credible claim for asylum. To legitimate his story, Participant 10 thus uses his student leadership experience to reinvent himself as an iconic figure in democratization in Cameroon. The testimony captures the notion of a tragic vision whereby the ensuing pain and suffering are the consequences of the participant's dream of transforming his university into a centre of learning, and his grandiose visions of a Cameroon devoid of the marginalization of anglophones..$^{53}$

His testimony exemplifies how Cameroonian memories tended to capture grotesque experiences of political victimization in Cameroon. Here, the story transcends imagining his aspirations to articulating his tribulations as a political figure at home and while fleeing:

I remember sometime in June 1996, there was an attempted secession, a gendarme post 54 was attacked, and the next day I heard over the radio that I was involved in the whole process. Everything that happened around the country I was linked to or blamed for, as I was the master minder. Sooner, I heard I was needed in Yaounde that I was sponsoring these things, inciting violence, but I was never part of the process. At some stage, I felt my life was no longer secure in the country. My access to space and rights were no longer secure. It was a question of whether I could be arbitrarily arrested

(C) Ernest A. Pineteh and Thecla N. Mulu, 2016. This open-access work is licensed under a Creative Commons AttributionNonCommercial 4.0 International License, which permits use, reproduction and distribution in any medium for non-commercial purposes, provided the original author(s) are credited and the original publication in Refuge: Canada's Journal on Refugees is cited. 
and detained or just killed. I knew it was one of the two options. I just thought this was the time for me to leave the country. 55

Although the narrative indicates a case of mistaken identity or wrongful accusation, the interviewee elevates this experience of insecurity into a life-threatening episode, portraying himself not just as a victim but more importantly as a 'flawless hero and the potent icon. ${ }^{56}$ However, the image of political hero is immediately juxtaposed with the image of fugitive because of his supposed role in the outcome of the political events. Whilst the informant represents himself as an emerging political leader, this identity fluctuates ambivalently with the identity of a victim, again foregrounding the legitimate claimant who achieves his vision through suffering and pain. This narrative style is repeatedly used in many Cameroonian testimonies as the "favourite medium for articulating [their] outrage and frustrations." 57 It highlights the concept of "plurality of identities," a strategy used by forced migrants "for social action and integration." 58 This asylum applicant consciously assumes "different identities sometimes differing and antagonistic"59 to strengthen and legitimize his case.

To show that Cameroon is indeed a fractured political system, the Cameroonians in the study tended to represent themselves as victims and fugitives in the political struggle in Cameroon. This narrative trajectory was used to establish well-founded fear of persecution as stipulated in the Geneva Convention. ${ }^{60}$ For example, the memory patterns involved describing how they escaped a culture of victimization and the imaginative evocations that mirrored their experiences of flight and exile. ${ }^{61}$ The escape stories were clearly accounts of extreme pain and suffering. One participant's experience of flight exemplifies such accounts:

At one stage I had a visa to Canada, I had an admission into the University of Toronto, and at the airport I was arrested and my passport seized, and the only explanation was that my name was in the "black book," a book containing names of people who are not supposed to leave the country. Somehow because I had meditated prior to attempting to leave the country, somehow everything was taken from me and I was asked to go back. I just think that everything held constant and typical of how the regime operates, I would have been arrested and detained ... Now, that was actually the second attempt to leave the country; the Canadian attempt I could not make, my passport seized with a visa inside. The Germany attempt was also the same, and so were many others. At that point I knew that I was not ever going to be able to free myself from that bondage. ${ }^{62}$

Narrating his experience of flight, the participant's memory is fraught with moments of psychological and physical pain. This excerpt captures his fear for his life and the figure of a courageous individual struggling through misfortune and disappointment to find resolution. This participant used episodes of insecurity to represent his life as an embodiment of human suffering. These episodes of disappointment and distress render his experience of flight a narrative of the misfortunes of a sympathetic protagonist faced with the "facts of cruelty, failure, frustration and loss." 63 In this excerpt, fear is used as a metaphor to show how the forced migrant's ancestral home "has created a new order of uncertainty in social life, an order that legitimizes responses of extreme violence and terror." 64

Episodes of misfortune, pain, and despair dominated the participants' memories of displacement, and the evocation of sympathy was these asylees' main narrative technique. Since judicial testimonies involve judgment, accusation, and defence, they had to ensure that their stories would appeal to the adjudicators. ${ }^{65}$ In the testimony of one participant, his journey of survival was constructed as a powerful narrative of sorrow, and his tragic sense of life during this period was that of suffering. His ordeal took him into the DRC, where the journey was made more frightening because of war and disturbing human rights abuses. As he narrated his journey from Cameroon to the DRC,

I had to go across the border to Brazzaville, and there was a huge checkpoint ahead. I knew they would get everybody out and inspect them. So the only thing I had to do was to pay the luggage guys to pack me up as luggage amongst other luggage. That was my worst experience ... I thought I was going to die because it was so hot, and I think I have never been in a hotter environment. It was like in the desert and I was tied up there, and for that I paid the guys 100 dollars ... We went past the checkpoint, the customs actually climbed on the luggage and I was actually under. ${ }^{66}$

Asylum-seekers in South Africa "are pushed by the institutional context to present acceptable accounts of narrated events and of themselves as actors in them." ${ }^{7} 7$ Their stories therefore tend to concentrate on accounts of emotionally and physically challenging events, which they ultimately survive. The painful features of loss of status and value are evident when Participant 8 is dehumanized through being reduced to luggage. Apart from the demeaning treatment of human beings, the quotation also exposes the endemic corruption in francophone sub-Saharan African countries including Cameroon, indicated in the ease with which he could bribe "the luggage guys."

The final stage of the account of another participant's escape from his homeland is seen in his narrative of his journey from the DRC (formerly Zaire) to Zambia:

In Limumbashi, Zaire, my application for a visa was rejected on grounds that I had to seek asylum first in Zaire, but I had a feeling 
that if I did so, something would go wrong ... I rejected the Zaire option and went to the UN, said, "Look, these are my fears and please process them the way you want, otherwise I strongly believe that I deserve political asylum." I was interviewed and granted asylum. Two weeks later, I applied to leave the country and I was issued a "laissez-passer," which I used to proceed to Zambia ... I arrived at Kasumbelesa, the border town between Zaire and Zambia, I was arrested. And when I showed the UN "laissez-passer," they said, "We cannot recognize this because the country is under a state of emergency" ... I was simply dumped in jail. I was in jail for six months without any judgment or access to lawyers. ${ }^{68}$

In this episode, the narration of arrest and subsequent imprisonment in Zambia echoes the melancholic experiences of forced migrants. In this case, the narrative of victimhood is again strongly foregrounded, focusing on pain, suffering, and despair. This participant is victimized not for any wrongdoing but for "being a strong character in an exposed position." 69 The image of an existentialist character also emerges as the participant continues to take responsibility for his actions and destiny, thus embracing the possibility of danger, and distress on his journey to exile..$^{70}$ This exilic experience is worsened by the degree of human rights abuse captured in this quotation.

While in Johannesburg, Cameroonian memories of this cosmopolitan space, especially in the early days, were reminiscent of the experiences of victimization at home and during the process of fleeing..$^{71}$ For example,

When I arrived South Africa, I couldn't get a job immediately, so I had to survive on financial assistance from friends and relatives. After a couple of months, my wife joined me with our baby, and life was even tougher. Then I knew I had to struggle harder because I had a wife and kid to look after. In fact during those days we were living in a single room, sleeping on the floor ... After struggling to get a job for quite some time, I began to think Johannesburg was not the city of gold after all. Moreover, the place was so risky, and crime was all over the place, and the people were terrible and were not interested in opening their doors to foreigners. ${ }^{72}$

The narrative of disillusionment articulated in this excerpt invokes sympathy and expresses one basic element of the "tragic sense of life," which is "the permanence and the mystery of human suffering"73 characterized by irremediable misfortunes. The participant's state of joblessness and the increasing feeling of rejection by South African nationals illustrate the experiences of most Cameroonian asylum-seekers and refugees "confronted with a restrictive immigration regime and high level of xenophobia." 74 Despite the challenges that confronted forced migrants in Johannesburg at that time, this respondent does not despair or abandon life but continues to fuel a strong desire for success and self-determination.

His heroic actions during the struggle for survival culminate in a seemingly kinder phase as his life begins to take shape after years in Johannesburg. The end of painful personal experiences opens a new phase in his life after more than six years in the city:

I think my life today is better than it was a few years back. I have a good job today and driving a good car. I am also living in my own house with my family. I think I have achieved a lot and I want to believe the days of suffering are over. 75

In this vignette, the ending of this participant's testimony represents a narrative of hope and resilience, evident in the reversal of his experiences during his early days in Johannesburg. The quotation illuminates the multiple contours of Cameroonian lives in Johannesburg and how the city has become a "palimpsest in which new patterns of investment, belonging and mobility ... over social fragmentation and new patterns of migration."76

In describing tragic and heroic moments in their lives, these Cameroonians have offered snapshots of autobiographical memory whereby the narrators have astutely and self-consciously fashioned their personal lives. They have constructed their subjective diasporic experiences against the backdrop of broader socio-political issues in Cameroon and in South Africa. This means that "autobiographical memory episodes play strong directive roles in people's lives in several different ways such as anchors of personal values, as originating events for chosen life directions and turning points that redirect one's life path."77

Like many Cameroonian stories of exile, the interviewees' testimonies began with the construction of their personal backgrounds, before delving into constructing their political identities and culminating in their experiences at home and in Johannesburg. One of the participants testifies,

I am a teacher and deputy principal of a private high school and a student as well ... As you know I come from the notorious town of Bamenda, precisely Awing in the North West province ... a very lovely city, quite cosmopolitan, welcoming, and a peace-loving people. But ... it is a notorious city when it comes to politics. It is the hard core of the opposition and the city that has given the ruling party the toughest of times. I think you know the place; it is the birthplace of the $\mathrm{SDF}^{78}$ and multi-party politics in Cameroon. My parents are strong supporters of the SDF and so are my other siblings. I grew up believing in what my parents believed in. ${ }^{79}$

In this narrative, the characteristics of an autobiographical memory begin to emerge as the respondent constructs

(C) Ernest A. Pineteh and Thecla N. Mulu, 2016. This open-access work is licensed under a Creative Commons AttributionNonCommercial 4.0 International License, which permits use, reproduction and distribution in any medium for non-commercial purposes, provided the original author(s) are credited and the original publication in Refuge: Canada's Journal on Refugees is cited. 
her personal life, privileging her family and ethnic origin. Her political identity is formulated against the background of her family's political history and the fact that she is from Bamenda, a city considered by many Cameroonians as the most rebellious and the stronghold of the main opposition to the ruling party. ${ }^{80}$ Here, the participant's memory of family is used to illuminate the relationship between her family values and her political life. She became an ardent supporter of the Social Democratic Front partly because of his parents' affiliations to the party, seemingly continuing her family political history. In Cameroonian applications for asylum, the city of Bamenda and the Social Democratic Front feature prominently in the narrators' memories because of their symbolic role in the struggle for political emancipation in Cameroon. The merits of their stories depend on the way they have associated themselves with these spaces. Their autobiographical memories are therefore "modified and refined to maintain and protect the self." ${ }^{11}$

In this light, Participant 3 uses her family background as a preamble to her political career and frames her story around this preamble. After narrating her family background, her testimony delves into a representation of her own illustrious political history:

I had been very active in our political domain back home since the launch of the SDF. I was a member of the SDF; in fact I was the secretary of my ward, member of the Amnesty International Group, and also a strong activist in the Southern Cameroon National Council (sCNC). ${ }^{82}$

In attempting to narrate a captivating political story, this participant reconstructs her political life and the significance of her persona within the political setting in Cameroon. By positioning her memory within the realms of the SDF and SCNC, she becomes an iconic figure in two oppositional but important movements in Cameroon's political history: the struggle for multiparty politics, represented by the SDF, and the struggle for an anglophone identity, represented by the sCNC. ${ }^{83}$ Because of the way she positions herself in these political movements, her narrative emerges as a form of "self-fashioning," captured through the repetitive use of the personal pronoun $I$ and the self-construction of an icon in a context as dangerous as Cameroon. The participant's political consciousness and the representation of herself as an important political symbol is one of many strategies used by Cameroonian asylum-seekers to justify claims that their lives were actually in danger and they had to flee the country.

The imagined pivotal roles played by Cameroonian asylum-seekers in the political struggle in Cameroon, supposedly positioning them as prime targets of the ruling party, justify their fears of political persecution. In these cases, this autobiographical memory "is a marker of credibility" 84 in that it is a typically self-styled narrative of a forced migrant's carefully selected experiences of flight and exilic conditions in Johannesburg. Another participant's experience of flight is not as crippling as that of other Cameroonian exiles:

I can tell you safely and soundly that I was lucky to have a brother with great connections. Through one top military officer, I was smuggled through Douala International Airport and 1 flew straight to South Africa without a break ... I really did not go through the fleeing trauma like most of my brothers who had to flee through different war-torn countries like DRC, Rwanda, and so on. I had a really smooth trip and that was how I got to Johannesburg. ${ }^{85}$

Although this respondent describes his journey from Cameroon to South Africa as comfortable, his early experiences in Johannesburg were similar to those of other participants. Again, the central features of autobiography memory are brought to the fore as the respondent captures and reconstructs his initial illusory impressions of Johannesburg and juxtaposes these impressions with his early experiences in the city:

I was completely overwhelmed by the infrastructure of the city. It is quite a magnificent place that gave me a different perspective about home. But after living in the city for a couple of days, I discovered that the people were not as beautiful as the city itself. I thought a beautiful city without a welcoming population meant absolutely nothing. We were not welcomed here as you know; we were styled makwere-kwere, rejected, and insulted. In fact the people were not friendly at all ... It was a strange place then, and you had to live life by the day not knowing what was going to happen to you the next moment. ${ }^{86}$

The participant's memory is a reconstruction of his personal experiences in Johannesburg and his perceptions of the city, narrating difficulties as symptomatic of wider social and economic problems affecting forced migrants. ${ }^{87}$ This autobiographical memory represents the displaced self, caught in the web of social evils of post-apartheid Johannesburg, and emphasizes how the narrator courageously managed to survive. Furthermore, by constructing his personal life along the axis of broader social realities of Johannesburg, Participant 5's memory is the re-storying of multiple personal versions of the city of Johannesburg common to other Cameroonian testimonies. ${ }^{88}$

In the foregoing sections, autobiographical memories are constructed against the backdrop of personal interpretations of political events both at home and in exile. The inclusion of key political events has a powerful bearing on 
the representation and invention of the self in the stories, as well as on the legitimacy of claims for asylum. ${ }^{89}$ Firstly, the narrators continually construct themselves as either victims or heroes in landmark political events at home, and secondly, in plotting the realities of their lives, their "autobiographical memories involve, at the outset, a discourse of witness: accounts of happening in which one participated." 90 One participant states,

The reason why I call it an "unholy alliance" is because francophones think they own Cameroon and want to dominate the whole nation. That is why you hear of the struggle for an anglophone identity and the emergence of pressure groups such as $\mathrm{CAM}^{91}$ and sCNC fighting for an anglophone identity. Secondly, it is also a cultural issue because there is a big gap between anglophone and francophone cultures, making it difficult for the two to cohabit.92

In this episode, political significance assumes centre stage as the narrator attempts to assess and evaluate the relationship between anglophone and francophone asylumseekers. The participant claims to be an activist in the SCNC movement and thus remembers this political struggle with the air of a connoisseur. The primacy of this testimony is in the significant shift from the narrator's recreation of the self to an account of the political feud between anglophone and francophone Cameroonians. In this case, broader political discourse takes precedence over individual life story. By framing his memory around the knowledge of politics, the narrator attempts to provide a strong "definition and expression of self and in the experience of personhood."93 However, this interpretation is still linked to the narrator's political identity because of his activism in the SCNC struggle. Furthermore, because of his anglophone identity, he continues to be a victim of francophone domination in Cameroonian associations in Johannesburg. ${ }^{94}$

\section{Conclusion}

An analysis of Cameroonian memories of displacement as moments of pain, fear, sorrow, and distress has shown how respondents in this study have located the self within the political history of Cameroon and South Africa. The analysis was shaped by participants' experiences of flight re-storied to be "perceived to be more believable and credible."95 Examining the twenty participants' stories, we argue that Cameroonian memories focus primarily on retrieving deeply emotional experiences of homelessness and exile and the possibilities of overcoming these challenges. The plots of their stories are constructed against the backdrop of specific events, as the narrators represent themselves as victims in a tragic story at one level and at another level as self-made heroes. Using the principles of memory construction, autobiographical memory, and the politics of storytelling as conceptual lenses, this article has attempted to examine how personal memories of displacement are constructed, distorted, and/or fashioned to render them credible and believable. The article concentrated on the strategies that Cameroonian asylum-seekers use to reinvent themselves in public spheres and political discourses. Here, the article has shown how memories of forced displacement represent "human reality, reality as it is for beings, who live in situations or contexts, and who are self-creating in that context." 96

\section{Notes}

1 J. Herlihy, K. Gleeson, and S. Turner, "What Assumptions about Human Behavior Underlie Asylum Judgments?," International Journal of Refugee Law 22, no. 3 (2010), 352.

2 B. Graham, J. Herlihy, and C. R. Brewin, "Overgeneral Memory in Asylum-seekers and Refugees," Journal of Behavior and Experimental Psychiatry 45 (2014): 375. See L. Berg and J. Millbank, "Constructing the Personal Narratives of Lesbian, Gay and Bisexual Asylum Claimants," Journal of Refugee Law 22, no. 1 (2007): 1-31; Herlihy, Gleeson, and Turner, "What Assumptions about Human Behavior Underlie Asylum Judgments?"; J. Herlihy, L. Jobson, and S. Turner, "Just Tell Us What Happened to You: Autobiographical Memory and Seeking Asylum," Applied Cognitive Psychology 26 (2012): 661-76.

3 Graham, Herlihy, and Brewin, "Overgeneral Memory."

4 M. Baynham and A. De Fina, Dislocations and Relocations: Narratives of Displacement (Manchester: St. Jerome Publishing, 2005), 5.

5 J. Bruner, "Life as Narrative," Social Research 54, no. 1 (1987): 11-32. See E. A. Pineteh, "Memories of Home and Exile: Narratives of Cameroonian Asylum-Seekers in Johannesburg," Journal of Intercultural Studies 26, no. 4 (2005): 379-99; D. Saleeby, "Culture, Theory and Narrative: The Intersection of Meanings in Practice," Social Work 39, no. 4 (1994): 351-9.

6 J. Crush, "Criminal Tendencies, Immigrants and Illegality in South Africa," Migration Policy Brief no. 10 (2003). See A. Morris and A. Bouillon, eds., African Immigration to South Africa: Francophone Migration of the $1990 \mathrm{~s}$ (Pretoria: Protea and IfAs, 2001); S. Peberdy and J. Crush, "Rooted in Racism: The Origins of the Aliens Control Act," in Beyond Control: Immigration and Human Rights in a Democratic South Africa, ed. J. Crush, 18-36 (Cape Town: South African Migration Project, IDASA, 1998); E. A. Pineteh, "'The challenge of living here and there': Conflicting Narratives of Intermarriage between Migrants and South Africans in Johannesburg," African and Black Diaspora: An International Journal 8, no. 1 (2015): 71-85.

7 J. Crush, "Making Up the Numbers: Measuring 'Illegal Immigration' to South Africa, Southern Africa Migration

(C) Ernest A. Pineteh and Thecla N. Mulu, 2016. This open-access work is licensed under a Creative Commons AttributionNonCommercial 4.0 International License, which permits use, reproduction and distribution in any medium for non-commercial purposes, provided the original author(s) are credited and the original publication in Refuge: Canada's Journal on Refugees is cited. 
Project," Migration Policy Brief no. 3 (2001); E. A. Pineteh, "Narratives of Homelessness and Displacement: Life Testimonies of Cameroonian Asylum-Seekers in Johannesburg" (PhD diss., University of the Witwatersrand, 2007).

8 Pineteh, "Challenge of living here and there."

9 Saleeby, "Culture, Theory and Narrative," 351.

10 Baynham and De Fina, Dislocations and Relocations. See Graham, Herlihy, and Brewin, "Overgeneral Memory."

11 Baynham and De Fina, Dislocations and Relocations. See J. Dowd Hall, "'You must remember this': Autobiography as a Social Critique," Journal of American History, 85, no. 2 (1998): 439-65.

12 P. J. Eakin, Fictions in Autobiography: Studies in the Art of Self-Invention (Princeton, NJ: Princeton University Press, 1985). See R. Folkenflik, The Culture of Autobiography: Construction of Self-Representation (Stanford, CA: Stanford University Press, 1993).

13 D. K. Mumby, ed., Narrative and Social Control: Critical Perspectives (London: Sage Publications, 1993), 5.

14 Pineteh, "Narratives of Homelessness and Displacement."

15 M. G. Henderson, Borders, Boundaries and Frames (New York: Routledge, 1995), 4.

16 Dowd Hall, "'You must remember this." See Pineteh, "Narratives of Homelessness and Displacement."

17 M. Freeman, Rewriting the Self: History, Memory, Narrative (London: Routledge, 1993), 33.

18 Ibid. See L. Passerini, Memory and Totalitarianism (Oxford: Oxford University Press, 1992).

19 P. Chamberlayne, J. Bornat, and T. Wengraft, The Turn to Biographical Methods in Social Science: Comparative Issues and Examples (London: Routledge, 2000), 265.

20 P. Gqola, "Defining People: Analyzing Power, Language and Representation in Metaphors of the New South Africa," Transformation 47 (2001): 95.

21 Dowd Hall, "'You must remember this," 440.

22 D. Thelen, "The Postmodern Challenge of Introducing Past to Present: Teaching about Memories and Monuments," Perspectives in Education 14, no. 2 (1995): 119.

23 K. Nelson and R. Nivush, "The Emergence of Autobiographical Memory: A Social Cultural Developmental Theory," Psychological Review 3, no. 2 (2004): 486.

24 Herlihy, Jobson, and Turner, "Just Tell Us What Happened to You," 662.

25 Baynham and De Fina, Dislocations and Relocations. See Bruner, "Life as Narrative"; Herlihy, Jobson, and Turner, "Just Tell Us What Happened to You."

26 J. Swindells, The Uses of Autobiography (London: Taylor and Francis, 1995), 6. See J. Herlihy, P. Scragg, and S. Turner, "Discrepancies in Autobiographical Memories: Implications for the Assessment of Asylum-seekers: Repeated Interviews Study," BMJ 324 (2002): 324-7; Passerini, Memory and Totalitarianism.

27 W. Labov, The Language of Life and Death: The Transformation of Experience in Oral Narrative (Cambridge: Cambridge University Press, 2013). See D. Schiffrin, A.
De Fina, and A. Nylund, eds., Telling Stories: Language, Narrative and Social Life (Washington, DC: Georgetown University Press, 2010); M. Bal, Narratology: Introduction to the Theory of Narrative, 3 rd ed. (Toronto: University of Toronto Press, 2009); M. Jackson, The Politics of Storytelling: Violence, Transgression, and Intersubjectivity (Copenhagen: Museum Tusculanum, 2002).

28 Jackson, Politics of Storytelling, 13.

29 R. Atkinson, "Life Stories, Autobiography, and Personal Narratives," LLI Review 41-3 (2011), 41.

30 M. Connelly and D. J. Clandinin, "Stories of Experience and Narrative Inquiry," Educational Researcher 19, no. 5 (1990): 2-14. See L. B. Landau and I. Freemantle, “Tactical Cosmopolitanism and Idioms of Belonging: Insertion and Self-Exclusion in Johannesburg," Journal of Ethnic and Migration Studies 36, no. 3 (2010): 375-90; Schiffrin, De Fina, and Nylund, Telling Stories.

31 B. Harris, "Xenophobia: A New Pathology for a New South Africa?" in Psychopathology and Social Prejudice, ed. D. Hook and G. Eagle, 169-84 (Cape Town: University of Cape Town Press, 2002). See L. B. Landau, ed., Exorcising the Demons Within: Xenophobia, Violence and Statecraft (Johannesburg: Wits University Press, 2011); Pineteh, "'Challenge of living here and there."

32 J. Crush, A. Chikanda, and C. Skinner, eds., Mean Streets: Migration, Xenophobia and Informality in South Africa (Ontario: South African Migration Project, 2015). See Harris, "Xenophobia"; Landau, Exorcising the Demons Within; Pineteh, "Challenge of living here and there."

33 K. Von Holdt and P. Alexander, "Collective Violence, Community Protest and Xenophobia," South African Review of Sociology 43, no. 2 (2011): 106.

34 Landau, Exorcising the Demons Within, 1.

35 Ibid., 6.

36 Landau and Freemantle, "Tactical Cosmopolitanism and Idioms of Belonging." See Pineteh, "'Challenge of living here and there."”

37 Harris, "Xenophobia," 175.

38 Ibid., 169.

39 Landau, Exorcising the Demons Within. See Landau and Freemantle, "Tactical Cosmopolitanism and Idioms of Belonging"; Pineteh, "Memories of Home and Exile."

40 Baynham and De Fina, Dislocations and Relocations, 3.

41 Dowd Hall, "You must remember this."”

42 Pineteh, "Narratives of Homelessness and Displacement"; Pineteh, "Challenge of living here and there."

43 D. M. Matsinhe, "Africa's Fear of Itself: The Ideology of Makwerekwere in South Africa," Third World Quarterly 32, no. 2 (2011): 296.

44 Crush, Chikanda, and Skinner, Mean Streets. See Landau, Exorcising the Demons Within; Pineteh, "'Challenge of living here and there."”

45 M. Cuesta, "How to Interpret Autobiographies," Razon y Palabra 16, no. 76 (2011): 9-17. See Harris, "Xenophobia"; Pineteh, "Memories of Home and Exile." 
46 Pineteh, "Memories of Home and Exile"; Pineteh, "Challenge of living here and there."”

47 Herlihy, Jobson, and Turner, "Just Tell Us What Happened to You," 266.

48 Pineteh, "Memories of Home and Exile;" Pineteh, "Narratives of Homelessness and Displacement."

49 Ibid.

50 The General Certificate of Education Board is a state institution responsible for managing all secondary and high school exit examinations in English medium schools.

51 Participant 10.

52 R. B. Sewall, The Vision of Tragedy (New Haven, ст: Yale University Press, 1959), 47.

53 D. Eyoh, "Conflicting Narratives of Anglophone Protest and the Politics of Identity in Cameroon," Journal of Contemporary African Studies 16, no. 2 (1998): 249-65.

54 The gendarme is a French military regiment and a legacy of the French colonial rule in Cameroon.

55 Participant 10.

56 Swindells, Uses of Autobiography, 47.

57 B. Lindfors, African Textualities: Texts, Pretexts and Contexts in African Literature (New York: Africa World, 1997), 147.

58 D. Hack-Polay, "Identity Denial and Borrowing among Forced Migrants in Host Countries: A Discursive Psychological Perspective," International Journal of Psychological Studies 5, no. 3 (2013): 13.

59 Ibid., 13.

6o Herlihy, Gleeson, and Turner, "What Assumptions about Human Behavior Underlie Asylum Judgments?"

61 Pineteh, "Memories of Home and Exile"; Pineteh, "Narratives of Homelessness and Displacement."

62 Participant 10.

63 Sewall, Vision of Tragedy, 46

64 P. Riano-Alcala, "Journeys and Landscapes of Forced Migration: Memorializing Fear among Refugees and Internally Displaced Colombians," Social Anthropology 16, no. 1 (2008): 4.

65 Baynham and De Fina, Dislocations and Relocations. See Pineteh, "Memories of Home and Exile"; Pineteh, "Narratives of Homelessness and Displacement."

66 Participant 8.

67 Baynham and De Fina, Dislocations and Relocations, 3.

68 Participant 7.

69 R. P. Draper, ed., Tragic Developments in Criticisms (London: Macmillan, 1980), 160.

70 Baynham and De Fina, Dislocations and Relocations, 3.

71 Pineteh, "Memories of Home and Exile"; Pineteh, "Narratives of Homelessness and Displacement."

72 Participant 11.

73 Sewall, Vision of Tragedy, 6.

74 Landau and Freemantle, "Tactical Cosmopolitanism and Idioms of Belonging," 376.
75 Participant 11.

76 Landau and Freemantle, "Tactical Cosmopolitanism and Idioms of Belonging," 377.

77 Herlihy, Jobson, and Turner, "Just Tell Us What Happened to You," 663.

78 Social Democratic Front (SDF) is the main opposition political party in Cameroon.

79 Participant 3.

80 Eyoh, "Conflicting Narratives of Anglophone Protest"; Pineteh, "Narratives of Homelessness and Displacement."

81 Herlihy, Jobson, and Turner, "Just Tell Us What Happened to You," 663.

82 Participant 3.

83 Eyoh, "Conflicting Narratives of Anglophone Protest." See also P. Konings, "Anglophone University Students' Revolts, Ethnic Militia and Violence of Political Liberalisation in Cameroon," African Studies Review 45, no. 2 (2002): 179-204.

84 Graham, Herlihy, and Brewin, "Overgeneral Memory," 375.

85 Participant 5.

86 Ibid.

87 G. M. Kenyon and W. L. Randall, Restorying Our Lives: Personal Growth through Autobiographical Reflection (Westport, СT: Praeger, 1997). See Landau and Freemantle, "Tactical Cosmopolitanism and Idioms of Belonging"; Swindells, Uses of Autobiography.

88 Landau and Freemantle, "Tactical Cosmopolitanism and Idioms of Belonging."

89 Graham, Herlihy, and Brewin, "Overgeneral Memory."

90 R. Folkenflik, ed., The Culture of Autobiography: Construction of Self-Representation (Stanford, CA: Stanford University Press, 1993), 45.

91 Cameroon Anglophone Movement was a pressure group that fought for the rights of anglophone Cameroonians.

92 Participant 2.

93 Herlihy, Jobson, and Turner, "Just Tell Us What Happened to You," 661.

94 Pineteh, "Memories of Home and Exile"; Pineteh, "Narratives of Homelessness and Displacement."

95 Herlihy, Jobson, and Turner, "Just Tell Us What Happened to You," 667.

96 Kenyon and Randall, Restorying Our Lives, 18.

Ernest A. Pineteh is a senior lecturer and researcher in the Unit for Academic Literacy at the University of Pretoria, South Africa. He may be contacted at pineteh.angu@up.ac.za.

Thecla N. Mulu is a doctoral candidate in the School of Government at the University of the Western Cape, South Africa. She may be contacted at teklamuluh@yahoo.com.

(C) Ernest A. Pineteh and Thecla N. Mulu, 2016. This open-access work is licensed under a Creative Commons AttributionNonCommercial 4.0 International License, which permits use, reproduction and distribution in any medium for non-commercial purposes, provided the original author(s) are credited and the original publication in Refuge: Canada's Journal on Refugees is cited. 